\title{
Research on Basketball Teaching Reform in Colleges and Universities
}

\author{
Haidong Liu ${ }^{1}$, Nana $\mathrm{Li}^{2}$, , Jiehua $\mathrm{Ma}^{3}$, and Bo Chen ${ }^{4}$ \\ ${ }^{1}$ School of Physical Education, Chengdu Normal University, Chengdu, China, 611130 \\ ${ }^{2}$ Graduate School of Chengdu Sport University, Chengdu, China, 610041 \\ ${ }^{3}$ Graduate School of Chengdu Sport University, Chengdu, China, 610041 \\ ${ }^{4}$ School of Physical Education, Chengdu Normal University, Chengdu, China, 611130
}

Keywords: colleges and universities, basketball courses, teaching ideas, teaching reform

Abstract: This article analyzes the college basketball teaching reform ideology, the status quo of basketball teaching in colleges and universities, and the influencing factors of college basketball teaching through literature analysis and exemplification. It then proposes the reform trend of basketball teaching in colleges and universities and provides a certain degree of basketball teaching for colleges and universities. References allow students to exercise themselves through the selection of a basketball program and benefit from it for life.

\section{Study on Basketball Teaching Reform Ideas in Colleges and Universities}

\subsection{College Sports Thought}

With the development of education in our country, in the process of basketball teaching reform, colleges and universities in our country should carry out reforms based on the needs of social development and on the basis of promoting the development of sports and cultivating the students' overall quality. Students should be "happy education" and "health education". With "lifelong education", we can achieve teaching goals. By studying the reform of college sports teaching methods in China, we can find that from the 1950s to the present, we can mainly be divided into onedimensional sports concept, two-dimensional sports concept, three-dimensional sports concept, and multi-dimensional sports concept. After these several stages, physical education teaching in colleges and universities in China can achieve good results both in theory and in practice. At the same time, the content of physical education in colleges and universities is also diversified, and a single teaching method can no longer meet the teaching requirements. Therefore, with the development of our country's economy, our country's college sports ideology has been transformed into an ideological system centered on cultivating students' comprehensive ability. In the process of constructing college sports ideas, foreign advanced teaching ideas and teaching methods should be studied so that they can be applied to China's current stage of physical education teaching ideas and teaching methods. 


\subsection{College Basketball Teaching Ideas}

Through research, we can find that the traditional sports teaching concept emphasizes single-sports skill teaching. A single teaching method over time will affect students' interest and enthusiasm for learning, and affect the exertion of students' individual abilities. It is unfavorable for students' overall development in the future. of. At this stage, the demand for talents in society has also changed. "Society needs determine educational goals and directions, and also stipulates the goals and direction of physical education courses. " ${ }^{[1]}$ Colleges and universities need to reform their teaching methods to socially-needed talents in accordance with social requirements. In the process of basketball teaching reform, we must not only attach importance to cultivating students' motor skills, but also need to cultivate students' ideology and quality and improve their overall quality. In basketball teaching activities, teachers should do a good job of teaching in the following aspects: selecting teaching content according to student needs; innovating teaching methods to stimulate students' interest in learning; and actively carrying out extra-curricular sports activities. Teachers should take a variety of ways to stimulate students' enthusiasm for learning, help students to develop good exercise habits, and establish a "lifetime sports" consciousness, so as to lay a foundation for students' all-round development in the future.

\section{Status Quo of Basketball Teaching in Colleges and Universities}

\subsection{Ignore Basketball's Entertainment}

In recent years, with the changes in the demand for talents in the society, China's education has also undergone a series of reforms. During the reform process, we found that there are some deficiencies in college basketball teaching, which affects the quality of basketball physical education and students' overall quality level in colleges and universities. "Tracing the roots, basketball originated from the game. It first appeared as a simple game and gradually developed into an athletic sport with a wide range of influence. For more than 100 years, basketball has never broken away from the basic characteristics of the game." ${ }^{[2]}$ Basketball as a sport activity not only has competitive, cooperative, technical features, but also has the characteristics of entertainment. However, most colleges and universities in the process of basketball teaching, teachers attach too much importance to training students' basketball skills, in the class teaching is more to teach students basketball skills, ignoring the entertainment of basketball, only allow students to fully appreciate the participation. Only by allowing students to fully appreciate the joy of participating in basketball can it inspire students' interest in basketball. Interest is the best teacher. Therefore, if the basketball entertainment is not fully displayed in teaching activities, it is not conducive to achieving basketball teaching goals.

\subsection{The Teaching Content is Boring and the Teaching Methods are Simple}

Basketball is a highly cooperative sports program with competitive and confrontational characteristics. This sport is also loved by many students, but these students are not interested in the basketball courses offered by the school. The reason is that college basketball teachers only teach students basic basketball skills in teaching activities. Then it is boring practice. "The relationship between traditional theory and practice shows that practical knowledge is superimposed on theoretical knowledge and that theoretical knowledge is the basis of practical knowledge. Practice is only the result of theoretical deduction. It is believed that only by fully mastering theoretical knowledge can we practice. It may develop practical ability." ${ }^{\text {"3] }}$ Because the teacher simply explained the skills of the movement technique, it did not pass the practice of the competition. The way to fully demonstrate the cooperation and competitiveness of basketball sports has seriously affected students' enthusiasm 
for learning. In addition, the teaching methods used by teachers are relatively single. Throughout the teaching activities, teachers used the same teaching methods and did not discriminate and teach students in accordance with their aptitude. This reduced the quality of teaching.

\subsection{Teaching Evaluation is not Scientific}

Some colleges and universities neglect the role of teaching evaluation in the process of basketball teaching. For example, some college PE teachers only take one or two lessons at the end of the period to examine students' basketball skills and score according to their performance. This evaluation method is not scientific and does not fully demonstrate the learning effect of students and students' basketball skills. The mastery of knowledge is also an important factor in reducing students' interest in learning.

\section{Research on Influencing Factors of Basketball Teaching in Colleges and Universities}

\subsection{Principles and Policies of Physical Education Reform in Colleges and Universities}

The country's principles and policies are formulated on the basis of the party's development line and are also the principle guiding the country's development direction. The reform of physical education in colleges and universities will also be affected by the policy guidelines of the state. The national policy and education are closely linked. Basketball teaching, as an important part of physical education, has also been influenced by the state's education policy. At the Third Plenary Session of the 18th Party Central Committee, the reform goal of "strengthening physical education and extracurricular training to promote physical fitness" was proposed. This is of great significance to the development of sports teaching in colleges and universities in China.

\subsection{Physical Education Resources in Colleges and Universities}

The physical education resources owned by colleges and universities are the basis to ensure the smooth progress of physical education. The quality of physical education resources also plays a decisive role in the quality of basketball teaching in colleges and universities. Under normal circumstances, physical education resources mainly include: physical education teaching grounds, teaching equipment, teaching content, teaching methods, and teacher resources. These teaching resources will have a direct impact on the quality of basketball teaching. A good teaching environment and advanced teaching equipment can effectively stimulate students' enthusiasm for learning, thus effectively improving teaching quality and effectiveness ${ }^{[5]}$. If the teaching resources are poor, it will affect the enthusiasm of students to learn basketball knowledge and basketball skills, and then affect the quality of basketball teaching. The quality of physical education teachers also has a qualitative impact on the quality of teaching. "In the source of physical education teachers, we should promote diversified development. " ${ }^{[4]}$ If physical education teachers have strong professional abilities and rich professional knowledge, physical education teachers can teach in easy and enjoyable way. The content of teaching is also more abundant. On the contrary, it will reduce the effectiveness of basketball teaching. It can be seen that college physical education resources will affect the quality and effectiveness of basketball teaching.

\subsection{College Basketball Teaching Content and Form}

Course content and teaching methods will also affect the quality of basketball teaching. The rich teaching content will expand students' knowledge and improve their professional skills. Easy teaching 
methods can effectively stimulate students' enthusiasm for learning, and thus improve the effectiveness of basketball teaching. On the contrary, boring, obsolete teaching methods and teaching content will affect the enthusiasm of students to learn, thereby reducing the effectiveness of basketball teaching. In order to meet the society's demand for talents, colleges and universities need to reform basketball teaching methods, change curriculum content, cultivate students' interest in basketball, and lay a foundation for the formation of lifelong sports awareness.

\section{University Basketball Teaching Reform Development Trend}

The quality of basketball teaching in colleges and universities plays an important role in cultivating college students' comprehensive quality and raising their awareness of cooperation and innovation. At this stage, with the development of economy, the college basketball teaching reform has also shown a new trend of development. The trend of college basketball teaching reform can be summarized as the following points.

\subsection{Lifelong Physical Education Concept}

Colleges and universities for the cultivation of social talent, colleges and universities should be based on the "health first" guiding ideology to set teaching goals, the development of physical education teaching goals should also tend to be healthy, personalized and lifelong." [5] In sports' teaching activities, it is necessary to help students develop good exercise habits and cultivate students' awareness of "lifetime sports" so as to lay a foundation for students' comprehensive development in the future. At the same time, with the development of education, the viewpoint of quality education has been put forward. In order to cultivate talents that meet the requirements of society, teachers need to integrate the concepts of quality education into college basketball teaching activities ${ }^{[7]}$. Students can learn basketball skills while training the overall quality of college students and lay a solid foundation for students' overall development in the future. For example, in the process of basketball practice teaching and basketball competition, students can develop cooperative ability, organizational ability, and reaction ability. By cultivating the overall quality of students, it will lay the foundation for students entering the society.

\subsection{Diversification of Basketball Assessment Methods}

With the concept of "student-centered" teaching, the evaluation methods of basketball teaching in colleges and universities are also developing in various directions. In evaluating the effectiveness of college basketball teaching, according to the actual situation of students, the development of appropriate assessment standards, full use of hierarchical assessment system, can fully reflect the student's learning results, such as: for students with good physical fitness, good basketball foundation, should be used Strict assessment methods; For poor physical fitness, weak basketball students, teachers should reduce the assessment criteria, add students' learning attitude, progress, daily performance, etc. as one of the assessment content, and enhance the enthusiasm of students to learn. Using this type of assessment can effectively stimulate students' interest in learning, and thus achieve the goal of improving teaching effectiveness.

\subsection{Reforming Traditional Teaching Methods}

In the traditional teaching activities, college sports teachers attach too much importance to teach the skills of basketball, ignoring the students to explain the theoretical knowledge of basketball, this teaching method can no longer meet the teaching needs. "The original purpose of physical education 
reform is to stimulate vitality through reforms so that students, families, and society can gain more benefits. " [6] Therefore, college PE teachers need to change their own teaching methods to explain theoretical knowledge of basketball and related rules to students. It is also necessary to explain to students the knowledge of the prevention and treatment of common sports injuries and to stimulate students' enthusiasm for learning so as to effectively improve the quality of basketball teaching. In addition, physical education teachers in colleges and universities should also conduct teaching based on students' learning ability and knowledge level and scientifically formulate teaching goals.

\subsection{College Basketball Teaching Develops towards Entertainment}

With the development of economy, people's living standards have been continuously improved, people's demands for quality of life and their own health are increasing. People need to enrich their lives through various fitness and entertainment programs to satisfy their demands for health. Therefore, popular sports, leisure sports and other words appear in people's daily lives, and they are valued by people. For undergraduate students, students are more active in participating in recreational sports activities. Through exercise after school hours, students can achieve the needs of entertainment and physical fitness. Because of its competitive, fierce and antagonistic characteristics, basketball has determined that it is an extremely enjoyable sports event. Both the participants and the viewers can feel happy and satisfied. Therefore, college basketball teaching should also guide students to participate in or watch basketball, allowing students to experience the entertainment of basketball themselves, thereby improving the effectiveness of basketball teaching.

\subsection{Inspiring Learning Interest by Role Model}

The role of role models is enormous. Many students love basketball because they are influenced by excellent basketball players. In order to stimulate students' enthusiasm for learning, teachers can organize students to watch large-scale basketball games and explain basketball tactics and basketball skills to students so that students can improve their professional skills while watching. In addition, the school also needs to increase students' extra-curricular activities, through grades or classes, interschool basketball competitions, to cultivate students' cooperation and organization skills, inspire students' love of basketball, so that students can improve basketball tactics, basketball skills while communicating with other people. Then the quality of basketball teaching and teaching level etc. also can be improved.

\subsection{Basketball Teaching in Colleges and Universities Develops in the Direction of Popular Fitness and Competitive Sports}

At this stage, various colleges and universities in China often carry out some basketball leagues, and all colleges and universities have built their own basketball teams. This not only provided a platform for college students to participate in basketball, but also effectively promoted the development of college basketball sports. When the physical education teachers in colleges and universities conduct teaching activities, they not only need to give basketball players some theoretical knowledge and basketball skills training, but also need to guide ordinary students to perform basketball sports. That is to say, college basketball teaching activities should not only train professional basketball players, but also need to the students who love basketball are instructed to make basketball more popular. In addition, basketball as a competitive sport has competitive characteristics. College PE teachers need to cultivate students' basketball skills and basketball skills in the teaching process, and strengthen the training of students' physical fitness. In addition, they can enhance students while strengthening physical education and basketball ability. Therefore, the 
integration of mass fitness and competitive sports is an important development trend of college basketball teaching.

\section{Conclusion}

To sum up, in recent years, China' s education industry is evolving towards quality education. Basketball, as a popular sport, needs to constantly reform teaching methods. However, the corresponding reform of college basketball teaching requires: the features and different individual student's actual needs as the direction; seize the characteristics of the basketball movement; eliminate single skills teaching methods; attach importance to basketball's competitiveness and fun and entertainment. In order to enhance the attractiveness of basketball teaching to students, to meet student physiology, to develop the basic demands of the simultaneous development of psychology, only in this way can the basic education function of basketball be fully utilized, enable students to actively learn basketball knowledge and skills, foster the team spirit of solidarity and cooperation, and promote the further improvement of students' comprehensive quality, so that basketball teaching could become one of the classes that students love. Students can acquire athletic skills, and cultivate lifetime sports awareness in the class.

\section{References}

[1] Houzhong Qi, Hongwei Fan, Wanling Liu, Jie Min, Yue Ma. Thinking on the Teaching Reform of College Basketball Course [J]. Journal of Physical Education, 2010,17(08):68-71.

[2] Jingcheng Cao. Analysis and Attempt of Basketball Teaching Reform in Colleges and Universities[J]. Sports and Science, 2002(05):73-75.

[3] Lunhong Dong, Ying Rao. College Basketball Curriculum Reform Based on Project Curriculum Theory[J]. Journal of Physical Education, 2013, 20(06):74-77.

[4] Shihong Li. The Necessity of the Reform of Sports Specialized Education in Senior High School and the Problems and Implementation Strategy[J]. Journal of Physical Education, 2016, 23(01):121-126.

[5] Jinfeng Ma. Discussion on the Reform of Physical Education in Colleges and Universities in China[J]. Journal of Shandong Institute of Physical Education, 2014, 30(02): 105-109.

[6] Hong Sun, Xinmin Liu. New Vision of College Physical Education Reform-From the Pursuit of Sports Utility to the Protection of Student Sports Rights[J]. Journal of Xi'an Institute of Physical Education, 2015, 32(02):229-233.

1) Liu Haidong (1985-) male, Henan Jiaozuo, master (physical education training), lecturer, now working in the Physical Education College of Chengdu Normal University, mainly engaged in sports education training research;

2) Li Nana (1986-) female, Henan Jiaozuo, master (physical education training), teaching assistant, is currently a Ph.D. student at Chengdu Sports Institute, mainly engaged in physical education training research;

3) Ma Jiehua (1980 -), female, Chengdu, Sichuan, master (history), deputy editor, graduated from Sichuan University in 2006, is currently a Ph.D. student at Chengdu Sports Institute, mainly engaged in physical education and sports culture research;

4) Chen Bo (1981 - ), male, Sichuan Hanyuan, Master (Education Management), Associate Professor, graduated from Sichuan Normal University in June 2009. Currently working at the Physical Education College of Chengdu Normal University, mainly engaged in minority traditional sports. Cultural and physical education training research 